\title{
Future Prospects of Smallholder Dairy Production: Pragmatic Evidence from Crop-Livestock Farming Systems of an
} Economically Transforming State in India*

How to cite this article: Thirunavukkarasu, D., Narmatha, N., Doraisamy, K. A., Ramesh Saravanakumar, V., \& Sakthivel, K. M. (2019). Future prospects of smallholder dairy production: Pragmatic evidence from crop-livestock farming systems of an economically transforming state in India. Cuadernos de Desarrollo Rural, I6(84). https://doi.org/I0.III44/Javeriana.cdrı6-84.fpsd

Duraisamy Thirunavukkarasu ${ }^{\text {a }}$

Tamil Nadu Veterinary and Animal Sciences University,

India

dthirunavukkarasu@gmail.com

ORCID: http://orcid.org/0000-0002-3360-1908

Natchiappa Narmatha

Tamil Nadu Veterinary and Animal Sciences University,

India

ORCID: http://orcid.org/0000-000I-5966-326I

Kolathur Arumugam Doraisamy

Tamil Nadu Veterinary and Animal Sciences University,

India

ORCID: http://orcid.org/0000-0002-I397-2349

Velusamy Ramesh Saravanakumar

Tamil Nadu Veterinary and Animal Sciences University,

India

ORCID: http://orcid.org/0000-000I-929I-5088

Kokumadai Mottaiappan Sakthivel

Tamil Nadu Veterinary and Animal Sciences University,

India

ORCID: http://orcid.org/0000-000I-7789-256X

DOI: https://doi.org/I0.III44/Javeriana.cdrı6-84.fpsd

Redalyc: http://www.redalyc.org/articulo.oa?id=II760160005

Received: I8 July 20I8 I Accepted: o8 March 20I9 I Published: I5 August 2019

\footnotetext{
${ }^{a}$ Corresponding author. E-mail: dthirunavukkarasu@gmail.com
} 


\begin{abstract}
:
In the context of structural transformation of Indian economy, we examined the patterns of income, migration, milk marketing, dairy trends and future plans at the household level in Tamil Nadu state in south India. The study finds that majority of the dairy households in various farming systems have poor landholdings; belong to low or middle income classes; have one migrant in their families, and diversified sources of income. Given this backdrop, continuing dairy activity in the near future differed based on farming system and market opportunities. The majority were not willing to motivate the next generation to take up dairying as a profession.
\end{abstract}

Keywords: smallholder dairying, farm exit, future of dairying, rural livelihood

\title{
Perspectivas futuras de la producción lechera de pequeños agricultores: Evidencia pragmática de sistemas agropecuarios de un estado económicamente transformador en India
}

\section{Resumen:}

En el contexto de la transformación estructural de la economía india, examinamos los patrones de ingresos, migración, comercialización de la leche, tendencias en lácteos y planes futuros a nivel de los hogares en el Estado Tamil Nadu en el sur de India. El presente estudio encuentra que la mayoría de los hogares lecheros de diversos sistemas agropecuarios tienen fincas pobres, pertenecen estratos de ingresos bajos o medios, tienen un migrante en sus familias y fuentes diversificadas de ingresos. Con este telón de fondo, la actividad lechera continuada en el futuro cercano difirió con base en el sistema de agricultura y las oportunidades del mercado. La mayoría fueron se sentían dispuestos a motivar a la siguiente generación para que adoptaran la producción láctea como profesión.

Palabras clave: pequeños productores de leche, abandonar la agricultura, futuro de la industria láctea, subsistencia rural

\section{Perspectivas futuras da produção leiteira de pequenos agricultores: Evidência pragmática de sistemas agropecuários de um estado economicamente transformador na Índia}

\section{Resumo:}

No contexto da transformação estrutural da economia indiana, examinamos padrões de renda, migração, comercialização do leite, tendências em laticínios e planos futuros no nível das famílias no Estado Tamil Nadu no sul da Índia. O presente estudo constata que a maioria das famílias leiteiras de diversos sistemas agropecuários tem sítios pobres, pertencem a camadas de renda baixa ou média, têm um migrante na família e fontes diversificadas de renda. Com essa tela de fundo, a atividade leiteira continuada no futuro próximo diferiu com base no sistema de agricultura e as oportunidades do mercado. A maioria estive disposta a motivar à próxima geração a adotar a tal produção como profissão.

Palavras-chave: pequenos produtores de leite, abandonar a agricultura, futuro da indústria de lacticínios, subsistência rural

\section{Introduction}

In India, the contribution of agriculture sector (which encompasses livestock sector) to the national economy has declined from 30 to $14 \%$ in the last three decades with an increasing share of manufacturing and service sectors. An absolute decline of the population engaged in agriculture was also reported for the first time in Indian history with more than 23.7 million workforce quitting agriculture in 2004-05 to 2009-10 (Mehrotra, Parida, Sinha \& Gandhi, 20I4). The share of rural population has also declined from 72 to $68 \%$ between $200 \mathrm{I}$ and $201 \mathrm{I}$ and increasing urbanisation has occurred across the country. Thus, Indian economy is in a transformation phase (World Bank, 2008). Smallholder dairying, a sub-sector of Indian agriculture, is a livelihood option for more than 75 million rural households ( $44 \%$ of rural households), is now under a changing context. 
At the same time in recent past, there is a greater emphasis from the developmental agencies and researchers to use smallholder livestock (which includes smallholder dairy), as one of the pathways to move out from rural poverty. For this, increasing the productivity of dairy animals and tapping the emerging milk market in urban areas has often been considered as a sustainable pathway. A significant attempt in this direction has been made through intensification of dairying with technologies, establishment of dairy co-operatives (Udo et al., 20II) and opening of the dairy sector for private investment. Currently India produces about I64 million metric tonnes of milk / annum (Government of India, 2017) which is mostly from smallholder dairying activities. At the same time, the gross observation suggests that there are exit tendencies and reluctance among the younger generation in dairy farming families to take up it as a profession compared to non-farm sector. This paper aims to comprehend the social economic conditions of farmers, their nature of dairy farming, milk production and marketing avenues, income pattern, migration dynamics of the dairy households, income pattern and role of non-farm sector in the household income and trends in dairying households, and the future course of dairying indifferent farming systems in the context of changes in composition of economy and urbanisation. Added to above, this study tries to understand the association between above factors with farming systems. In this research, the above research gaps addressed in a logical sequence. The first section deals with introduction in addition to objectives, of the study. The second part deals with materials and methods adopted for the research. Added, the findings of this study are presented in "result" section. Based on the results, a detailed discourse is presented in discussion section. From above all a conclusion is drawn and is presented in last section of the paper.

\section{Materials and methods}

\section{Selection of province and adoption of typology}

The Tamil Nadu state of India, a highly urbanized state which reflects the composition of national economy and where the organized dairy sector has higher share of dairy market, was selected as study site. This state was one among the high milk producing provinces with organized marketing system handling two-fifth of the milk produced against the national average of $20 \%$. Added to above, $48 \%$ of the population in Tamil Nadu resides in urban areas (Chandramouli, 20II) and agriculture contributes to $14 \%$ to the state gross domestic economy (Government of India, 20I5). Thus, it was purposely selected to understand and foresee the future of smallholder dairy in the changing context.

Within the province, there were regional variations in terms of natural resources, climatic factors, infrastructure (e.g. road connectivity, access to market), availability of resources for dairy farming (e.g. water for cultivation of food-feed crops or fodder, access to grazing), non-farm sector opportunities, and social factors which have a predominant role in sustaining and shaping the course of smallholder production. Added to above, an understanding of farming systems may help developmental agencies and policy makers to develop specific interventions. 
For the above purpose, a typology of CLS (Crop-livestock systems) developed by Rao and Birthal (2008) with agro-ecological and socio-economic data of the period 1970 and 1998 was adopted for selection of study areas. This province has three different CLS namely CLS 5.3 , CLS I.0 and CLS 15.0 . The CLS 5.3 implies the presence of hot, moist, sub humid to humid agro-ecological region with high annual rainfall and low irrigation facilities. Milch animals account for $28 \%$ of the total value of agriculture production and majority ( $70 \%$ ) of farmers were small and marginal. At the same time, geographical spread of this system is very limited in the province. CLS I.o has high annual rainfall and irrigation with hot sub-humid to semi-arid tropical climate and has larger coastal plain. Milch animals account for $17 \%$ of the total value of agriculture production. CLS 15.0 denotes hot, semiarid agro-ecological region with low rainfall and irrigation facilities. Milch animals account for $9 \%$ of the total value of production in the farming system. In all the three farming systems, livestock accounts for more than one-fifth to one-third of total value of agricultural output and agriculture accounts for 63 to $68 \%$ of total value of production in the farming system output. Further, within the livestock sub-sector, dairying accounts for 50 to $70 \%$ of the total value of the livestock output (Rao \& Birthal, 2008).

\section{Selection of study areas}

Based on the cattle population, the taluks (an administrative sub-division within the state) in each crop-livestock system were categorized as high, medium and low cattle population taluks. Within each farming system, three taluks were selected for survey one representing low, one representing medium and one representing high cattle population. Thus, nine taluks representing three farming system were selected as research areas. These taluks are assumed to represent and reflect the agro-ecological and socio-economic characteristics of their crop livestock system.

\section{Data collection and analysis}

A semi structured interview schedule was developed in English to capture data on the sources of income, migration, non-farm sector contribution to family income, marketing, trends and future plans regarding dairying. The researcher translated the questions to vernacular language during individual interview of farmers. The information was collected from household person(s) engaged in dairying through individual recall of data. Data were collected from three villages representing low, three representing medium and three representing high cattle population within selected taluks (Table I). However, in one farming system, CLS 5.3 which has limited geographical spread, only one village was utilized to represent each selected taluk. Thus, three villages represented CLS 5.3, nine villages represented CLS ${ }_{\text {. }}$, and nine villages represented CLS 15.0 . From these 2I villages, data were drawn from $4 \mathrm{I} 0$ farmers based on farmer recall and their future plan on dairying during the period of 2015-16. The collected data were categorised CLS-wise to understand the influence of agro-ecological and socio-economic factors on smallholder dairy. The association between the farming system and sources of income, and income and migration were analysed using chi square tests and the data on the marketing, trends and future plans were analysed using descriptive statistics. 
TABLE 1

Distribution of selected farmers in crop livestock systems (CLS) of Tamil Nadu and cattle population of taluks

\begin{tabular}{|c|c|c|c|c|}
\hline $\begin{array}{l}\text { Name of the } \\
\text { CLS }\end{array}$ & District & Taluk & Grama panchayat & $\begin{array}{c}\text { Sample } \\
\text { size }\end{array}$ \\
\hline \multirow{3}{*}{ CLS 5.3} & \multirow[t]{3}{*}{ Kanyakumari } & $\begin{array}{l}\text { Agastheswaram } \\
\text { (Low-4158) }\end{array}$ & Paloor & \multirow{3}{*}{30} \\
\hline & & $\begin{array}{c}\text { Kalkulam } \\
\text { (Medium-4982) }\end{array}$ & Muzhucode & \\
\hline & & $\begin{array}{l}\text { Vilavancode } \\
\text { (High-8432) }\end{array}$ & Vilathurai & \\
\hline \multirow{9}{*}{ CLS 1.0} & \multirow[t]{3}{*}{ Tuticorin } & \multirow{3}{*}{$\begin{array}{c}\text { Sathangkulam } \\
\text { (Low-9531) }\end{array}$} & Thiruppaniputhantharuvai & \multirow{9}{*}{177} \\
\hline & & & Naduvakkurichi & \\
\hline & & & Pudukulam & \\
\hline & \multirow[t]{3}{*}{ Tirunelveli } & \multirow{3}{*}{$\begin{array}{c}\text { Tenkasi } \\
\text { (Medium-19,242) }\end{array}$} & Idaikal & \\
\hline & & & Kasidharam & \\
\hline & & & Avudaiyanoor & \\
\hline & \multirow[t]{3}{*}{ Nagapattinam } & \multirow{3}{*}{$\begin{array}{l}\text { Vedharnayam } \\
\text { (High- 37,735) }\end{array}$} & Pachanathikulam Middle & \\
\hline & & & Pushpavanam & \\
\hline & & & Karurpambulam & \\
\hline \multirow{10}{*}{ CLS 15} & \multirow[t]{3}{*}{ Vellore } & \multirow{3}{*}{$\begin{array}{c}\text { Ambur } \\
(\text { Low-23,226) }\end{array}$} & Aiyathambattu & \multirow{9}{*}{203} \\
\hline & & & Kumaramangalam & \\
\hline & & & Vengatasamudram & \\
\hline & \multirow[t]{3}{*}{ Erode } & \multirow{3}{*}{$\begin{array}{c}\text { Erode } \\
\text { (Medium-37467) }\end{array}$} & Karai ellapalayam & \\
\hline & & & Pundurai semur & \\
\hline & & & Nanjaiuthukuli & \\
\hline & \multirow[t]{4}{*}{ Dharmapuri } & \multirow{3}{*}{$\begin{array}{c}\text { Harur } \\
\text { (High-62,068) }\end{array}$} & Runganavalasai and Vadapatti & \\
\hline & & & Suramatham & \\
\hline & & & Tambal & \\
\hline & & & Total sample size & 410 \\
\hline
\end{tabular}

Source: own elaboration

\section{Results}

This study found that a majority of the smallholder dairy households in all the three farming systems were landless to small landholding farmers, possessed small herd size (i to 3 adult cattle) and majority owned crossbred milch animals. Dairying predominantly engages women and it is a profession of middle to old age members of the household (Table 2). But on comparing with other two systems, CLS 5.3 had a higher proportion of landless and marginal farmers $\left(\left(\mathrm{X}^{2}(8, \mathrm{~N}=4 \mathrm{IO})=30.79, \mathrm{P}=.00 \mathrm{I}\right)\right.$ and higher share of households owning high yielding Holstein dairy animals. Also, the majority of the dairy farming households in all the three systems belonged to lower to middle income classes in the rural society. Thus, dairying was more associated with marginalized sections of the agrarian class. 
TABLE 2

SElECted DEMOgRAPHiC FACTORS OF SMALLHOLdER DAIRY FARMERS IN DIFFERENT FARMING SYSTEMS (NUMBER AND PERCENTAGE OF FARMERS BY DEMOGRAPHIC FACTORS)

\begin{tabular}{|c|c|c|c|c|}
\hline \multirow[b]{2}{*}{ Category } & \multicolumn{3}{|c|}{ Crop livestock farming (CLS) system } & \multirow[b]{2}{*}{$\begin{array}{c}\text { Chi-square } \\
\text { value }\end{array}$} \\
\hline & $\begin{array}{l}\text { CLS } 5.3 \\
\text { No. }(\%)\end{array}$ & $\begin{array}{l}\text { CLS } 1.0 \\
\text { No. }(\%)\end{array}$ & $\begin{array}{c}\text { CLS } 15.0 \\
\text { No. }(\%)\end{array}$ & \\
\hline \multicolumn{5}{|c|}{ Landholding } \\
\hline Landless & $6(20.00)$ & $42(23.70)$ & $33(16.20)$ & \multirow{5}{*}{30.79} \\
\hline Marginal (up to 2.5 acres) & $23(76.70)$ & $81(45.80)$ & $73(36.00)$ & \\
\hline Small ( 2.5 to 5.0 acres $)$ & $1(3.30)$ & $26(14.70)$ & $52(25.60)$ & \\
\hline Semi medium ( 5.0 to 10 acres) & $0(0.00)$ & $18(10.20)$ & $26(12.80)$ & \\
\hline Medium ( 10.0 to 25.0 acres) & $0(0.00)$ & $10(5.60)$ & $19(9.40)$ & \\
\hline \multicolumn{5}{|c|}{ Income classes } \\
\hline Lower income & $2(6.70)$ & $48(27.10)$ & $32(15.80)$ & \multirow{5}{*}{14.21} \\
\hline Lower middle & $9(30.00)$ & $35(19.80)$ & $37(18.20)$ & \\
\hline Middle & $7(23.30)$ & $32(18.10)$ & $43(21.20)$ & \\
\hline Upper middle & $6(20.00)$ & $29(16.40)$ & $48(23.60)$ & \\
\hline Upper & $6(20.00)$ & $33(18.60)$ & $43(21.20)$ & \\
\hline
\end{tabular}

Number of sources of income

\begin{tabular}{|c|c|c|c|c|}
\hline Only farming & $3(10.00)$ & $48(27.10)$ & $52(25.60)$ & \multirow{4}{*}{11.59} \\
\hline Farming+ one non-farm & $21(70.00)$ & $81(45.80)$ & $86(42.40)$ & \\
\hline Farming+ two non-farm & $6(20.0)$ & $37(20.90)$ & $45(22.20)$ & \\
\hline $\begin{array}{l}\text { Farming + more than two non- } \\
\text { farm }\end{array}$ & $0(0.00)$ & $11(6.20)$ & $20(6.99)$ & \\
\hline
\end{tabular}

\begin{tabular}{|c|c|c|c|c|}
\hline \multicolumn{5}{|c|}{ Non-farm sector contribution to family income } \\
\hline No contribution & $3(10.00)$ & $48(27.10)$ & $52(25.60)$ & \multirow{5}{*}{17.56} \\
\hline Up to $25 \%$ & $1(3.30)$ & $8(4.50)$ & $18(8.90)$ & \\
\hline$>25$ to $50 \%$ & $8(26.70)$ & $28(15.80)$ & $42(20.70)$ & \\
\hline 50 to $75 \%$ & $9(30.00)$ & $42(23.70)$ & $59(29.00)$ & \\
\hline Above $75 \%$ & $9(30.0)$ & $51(28.90)$ & $32(15.80)$ & \\
\hline \multicolumn{5}{|c|}{ Migration intensity ( $\%$ of available man days) } \\
\hline No migration & $7(23.30)$ & $75(42.40)$ & $88(43.30)$ & \multirow{5}{*}{7.58} \\
\hline Up to $25 \%$ & $2(6.70)$ & $16(9.00)$ & $20(9.90)$ & \\
\hline 25 to $50 \%$ & $15(50.00)$ & $53(29.90)$ & $57(28.10)$ & \\
\hline 50 to $75 \%$ & $1(20.00)$ & $14(18.10)$ & $14(17.70)$ & \\
\hline Above $75 \%$ & $0(0.00)$ & $1(0.60)$ & $2(1.00)$ & \\
\hline
\end{tabular}

Source: own elaboration

$(n=30+177+203)$

Statistical significance: Land holding X CLS, $\mathrm{P}<0.00 \mathrm{I}$; non-farm sector contribution to family income X CLS, $\mathrm{P}<0.05$; dairying contribution to family income $\mathrm{X} C L S, \mathrm{P}<0.00 \mathrm{I}$; type of milch animals owned $\mathrm{X} C L S, \mathrm{P}<0.00 \mathrm{I}$. 
SElECted DEMOgRAPHiC FACTORS OF SMALLHOLdER DAIRY FARMERS IN DIFFERENT FARMING SYSTEMS (NUMBER AND PERCENTAGE OF FARMERS BY DEMOGRAPHIC FACTORS)

\begin{tabular}{|c|c|c|c|c|}
\hline \multirow[b]{2}{*}{ Category } & \multicolumn{3}{|c|}{ Crop livestock farming (CLS) system } & \multirow{2}{*}{$\begin{array}{l}\text { Chi-square } \\
\text { value }\end{array}$} \\
\hline & $\begin{array}{l}\text { CLS } 5.3 \\
\text { No. }(\%)\end{array}$ & $\begin{array}{l}\text { CLS } 1.0 \\
\text { No. }(\%)\end{array}$ & $\begin{array}{c}\text { CLS } 15.0 \\
\text { No. }(\%)\end{array}$ & \\
\hline \multicolumn{5}{|c|}{ Dairying contribution to family income } \\
\hline Up to $5 \%$ & $7(23.30)$ & $61(34.50)$ & $26(12.80)$ & \multirow{6}{*}{68.47} \\
\hline 5 to $10 \%$ & $4(13.40)$ & $12(6.80)$ & $27(13.30)$ & \\
\hline 10 to $15 \%$ & $3(10.00)$ & $19(10.70)$ & $25(12.30)$ & \\
\hline 15 to $20 \%$ & $0(0.00)$ & $13(7.30)$ & $25(12.30)$ & \\
\hline 20 to $25 \%$ & $1(3.30)$ & $13(7.30)$ & $17(8.40)$ & \\
\hline Above $25 \%$ & $15(50.00)$ & $59(33.40)$ & $89(40.90)$ & \\
\hline \multicolumn{5}{|c|}{ Adult milch animal holding pattern } \\
\hline One adult milch animal & $9(30.00)$ & $84(47.50)$ & $80(39.40)$ & \multirow{5}{*}{9.42} \\
\hline Two adult milch animals & $13(43.34)$ & $59(33.30)$ & $64(31.50)$ & \\
\hline Three adult milch animals & $6(20.00)$ & $20(11.30)$ & $32(15.80)$ & \\
\hline Four adult milch animals & $1(3.33)$ & $9(5.10)$ & $14(6.90)$ & \\
\hline Five adult milch animals & $1(3.33)$ & $5(2.80)$ & $13(6.40)$ & \\
\hline \multicolumn{5}{|c|}{ Type of milch animals owned } \\
\hline Jersey cross alone & $7(23.44)$ & $81(45.78)$ & $55(27.10)$ & 22.84 \\
\hline $\begin{array}{l}\text { Holstein cross with or without } \\
\text { Jersey cross }\end{array}$ & $23(76.66)$ & $90(50.84)$ & $127(62.56)$ & \\
\hline Buffalo alone & $0(0.00)$ & $6(3.38)$ & $21(10.34)$ & \\
\hline \multicolumn{5}{|c|}{ Age of family members engaged in dairying } \\
\hline Young age $(<35$ years $)$ & $7(23.30)$ & $25(14.10)$ & $27(13.30)$ & \multirow{3}{*}{5.22} \\
\hline Middle age ( 35 to $<46$ years $)$ & $7(23.30)$ & $54(30.50)$ & $77(37.90)$ & \\
\hline Old age ( 46 and above years) & $16(53.40)$ & $98(55.40)$ & $99(48.80)$ & \\
\hline \multicolumn{5}{|c|}{ Role of gender in dairying } \\
\hline Predominantly women & $12(40.00)$ & $83(46.90)$ & $75(36.90)$ & \multirow{3}{*}{6.36} \\
\hline Joint activity of men and women & $13(43.30)$ & $73(41.20)$ & $87(42.90)$ & \\
\hline Predominantly men & $5(16.70)$ & $21(11.90)$ & $41(20.20)$ & \\
\hline
\end{tabular}

Source: own elaboration $(\mathrm{n}=30+177+203)$

Statistical significance: Land holding X CLS, $\mathrm{P}<0.00 \mathrm{I}$; non-farm sector contribution to family income X CLS, $\mathrm{P}<0.05$; dairying contribution to family income X CLS, $\mathrm{P}<0.00 \mathrm{I}$; type of milch animals owned X CLS, $\mathrm{P}<0.00 \mathrm{I}$.

In terms of income sources, the data reveal that the overwhelming majority $(93.30 \%)$ of the households in CLS 5.3 and more than three-fourth households in other two farming systems had more than one source of income indicating diversification from farming (agriculture and allied sector) to non-farming (NF) income sources. The majority of the households in CLS 5.3 and CLS 1.0 had more than $50 \%$ of income from non-farm sector $\left(\mathrm{X}^{2}(8, \mathrm{~N}\right.$ $=410)=20.16, P=.05)$. The average contribution of non-farm sector to family income in CLS 5.3, CLS I.0 and CLS 15.0 was $55.94 \%(55.94 \pm \mathrm{SE} 5.42), 46.35 \%(46.35 \pm \mathrm{SE} 2.60)$ and $40.21 \%(40.2 \mathrm{I} \pm \mathrm{SE} 2.22)$ respectively. This income was generated through occupational diversification at the village-level and throughout migration. 
In terms of migration, nearing three-fifth of the households in CLS I.० and CLS 15.0 and more than threefourth households in CLS 5.3 had migration of minimum of one member. Half of the households in CLS 5.3 and more than one-fourth households in CLS I.0 and CLS 15.0 had spent 25 to $50 \%$ of man-days in migrated area. An

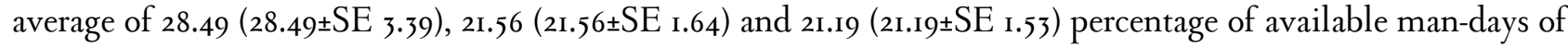
the households in CLS 5.3, CLS I.0 and CLS 15.0 respectively were spent in migrated areas to generate additional income.

In terms of dairying income, the present study finds that about one-third in CLS 1.0 , two-fifth in CLS 15.0 and half of the households in CLS 5.3 had more than $25 \%$ of the contribution from dairying to household income. In comparison, in CLS 1.0 one-third had less than $5 \%$ contribution from dairying $\left(\mathrm{X}^{2}(8, \mathrm{~N}=4 \mathrm{IO})=68.47, \mathrm{P}=.0 \mathrm{I}\right)$. Thus, a higher contribution of dairying was noticed in CLS 5.3 and CLS 15.0 . On an average, dairying accounted for 27.75

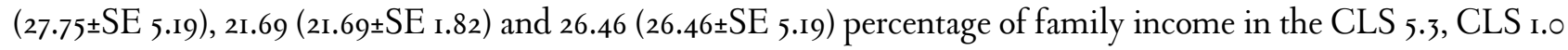
and CLS 15.0 respectively. Further, $98 \%$ of farmers in CLS 15.0 had access to organized dairies (private and / or dairy co-operatives) and hence better milk marketing opportunities (Table 3 ) in the farming system. More than three-fourth $(78.80 \%)$ farmers of CLS 15.0 were selling the milk to organized dairies. While in the CLS 1.0 and CLS 5.3, the farmers were predominantly selling milk to vendors and consumers respectively. In terms of price per litre of milk, the overwhelming majority (97\%) of CLS 5.3 received more than INR (Indian National Rupees) 25 and more than three-fifth and half of the farmers received INR 20 to 25 per litre of milk in CLS 15.0 and CLS I.O respectively. In addition, more than one-fourth received less than INR 20 per litre of milk. On an average, the sale price per litre of milk was INR $30.83(30.83 \pm \mathrm{SE} 0.87), 20.88(20.88 \pm \mathrm{SE}$ 0.76) and 23.19 (23.19 $\pm \mathrm{SE}$ 0.23) in CLS 5.3, CLS I.0 and CLS I5.0 respectively. Added to above, in CLS I.0, on comparing with other farming systems, more than one-fourth (26\% of households) proportion of the households sold $\circ$ to $50 \%$ of produced milk was sold.

The prime motives for dairy activities among the households were explored. It was found that more than twofifth households in CLS 5.3 and CLS 15 were carrying out dairy for generation of additional income. While in case of CLS I.0, about $44 \%$ were seeking to meet their own household demand for milk (more of subsistence nature) and $4 \mathrm{I} \%$ were seeking additional income. 
MILK MARKETING OPPORTUNITIES, SALES PATTERN AND PRICE RECEIVED FOR MILK BY SMALLHOLDER DAIRY FARMERS

\begin{tabular}{|c|c|c|c|}
\hline \multirow[b]{2}{*}{ Category } & \multicolumn{3}{|c|}{ Crop livestock farming (CLS) system } \\
\hline & $\begin{array}{l}\text { CLS } 5.3 \\
\text { No. }(\%)\end{array}$ & $\begin{array}{l}\text { CLS } 1.0 \\
\text { No. }(\%)\end{array}$ & $\begin{array}{l}\text { CLS } 15.0 \\
\text { No. }(\%)\end{array}$ \\
\hline \multicolumn{4}{|c|}{ Available milk marketing opportunities $(\mathrm{n}=30+177+203)$} \\
\hline No opportunity & $0(0.00)$ & $25(14.10)$ & $0(0.00)$ \\
\hline Only vendor* & $16(53.30)$ & $108(61.00)$ & $3(1.50)$ \\
\hline $\begin{array}{l}\text { Vendor with private or dairy co- } \\
\text { operatives }\end{array}$ & $14(46.70)$ & $37(20.90)$ & $126(62.10)$ \\
\hline $\begin{array}{l}\text { Vendor, private and co- } \\
\text { operatives }\end{array}$ & $0(0.00)$ & $7(4.00)$ & $74(36.40)$ \\
\hline \multicolumn{4}{|c|}{ Milk Sales pattern (multiple response) } \\
\hline Direct sale to consumer & $21(70.00)$ & $38(25.50)$ & $12(5.91)$ \\
\hline Institutional sale & $2(6.66)$ & $0(0.00)$ & $2(0.98)$ \\
\hline Vendor & $8(26.66)$ & $110(73.82)$ & $41(20.19)$ \\
\hline Dairy Co-operatives & $9(30.00)$ & $4(2.68)$ & $80(39.40)$ \\
\hline Private dairies & $3(10.00)$ & $2(1.34)$ & $80(39.40)$ \\
\hline \multicolumn{4}{|c|}{ Price received for milk per liter $(n=30+177+203)$} \\
\hline Up to INR $20 /-$ & $0(0.00)$ & $46(26.00)$ & $44(21.70)$ \\
\hline INR 20 to 25 & $1(3.30)$ & $93(52.50)$ & $123(60.60)$ \\
\hline More than INR 25/- & $29(96.70)$ & $38(21.50)$ & $36(17.70)$ \\
\hline
\end{tabular}

Source: own elaboration
INR: Indian national Rupee
65 INR = One US dollar
* Refers to small business man who procures roo to 200 litres per day and transports
through two wheeler and either sell it directly to consumers or processing industries.


TABLE 3 (CONT.)

MILK MARKETING OPPORTUNITIES, SALES PATTERN AND PRICE RECEIVED FOR MILK BY SMALLHOLDER DAIRY FARMERS

\begin{tabular}{|c|c|c|c|}
\hline \multirow{3}{*}{ Category } & \multicolumn{3}{|c|}{ Crop livestock farming (CLS) system } \\
\hline & CLS 5.3 & CLS 1.0 & CLS 15.0 \\
\hline & No. $(\%)$ & No. $(\%)$ & No. $(\%)$ \\
\hline \multicolumn{4}{|c|}{ Proportion of the milk sold } \\
\hline $0 \%$ (No sales) & $0(0.00)$ & $28(15.80)$ & $0(0.00)$ \\
\hline $25 \%$ & $0(0.00)$ & $3(1.70)$ & $0(0.00)$ \\
\hline 25 to $50 \%$ & $0(0.00)$ & $15(8.50)$ & $0(0.00)$ \\
\hline 50 to $75 \%$ & $1(3.30)$ & $7(4.00)$ & $11(5.40)$ \\
\hline Above $75 \%$ & $29(96.70)$ & $124(70.10)$ & $192(94.60)$ \\
\hline \multicolumn{4}{|c|}{ Primary reasons for keeping dairy animals $(n=30+177+203)$} \\
\hline Additional income to family & $19(63.30)$ & $72(40.70)$ & $135(66.40)$ \\
\hline Home consumption of milk & $5(16.70)$ & $77(43.50)$ & $47(23.20)$ \\
\hline Farm yard manure & $2(6.70)$ & $6(3.40)$ & $4(2.00)$ \\
\hline Other reasons & $4(13.30)$ & $22(12.40)$ & $17(8.40)$ \\
\hline \multicolumn{4}{|c|}{ Reasons for withdrawal from dairying (multiple response) } \\
\hline Inadequate income & $17(56.67)$ & $151(85.31)$ & $194(95.57)$ \\
\hline $\begin{array}{l}\text { Poor value system associated with } \\
\text { dairying }\end{array}$ & $8(26.67)$ & $112(63.27)$ & $162(79.80)$ \\
\hline Heavy work load & $5(16.67)$ & $60(33.90)$ & $48(23.64)$ \\
\hline $\begin{array}{l}\text { Employment Opportunity in } \\
\text { non-farm sector }\end{array}$ & $6(13.33)$ & $190(33.90)$ & $89(43.84)$ \\
\hline
\end{tabular}

Source: own elaboration

INR: Indian national Rupee

65 INR = One US dollar

* Refers to small business man who procures roo to 200 litres per day and transports

through two wheeler and either sell it directly to consumers or processing industries.

Farmers' perceptions of trends in dairying over the past ten years (Fig. I) and future plans was also elicited to understand the transition in smallholder dairying in the next five years (Fig. 2). This information needs to be treated with care since it is the perception of the farmers. Nearly two third of farmers in CLS 5.3, reported increase of herd size in last ten years. While nearing half of the farmers in CLS 1.0 and CLS ${ }_{15}$ reported a decline of herd size in their households. Milk production by four-fifth of farmers in CLS 5.3 has increased while two-fifth only reported an increase in milk production in CLS ${ }_{1.0}$ and CLS ${ }_{15}$. When asked about milk sales, almost all farmers in CLS 5.3 indicated an increase in sales of milk in the last ten years, bit this was not so in other systems. At the same time, in the case CLS I.O, more than two-third were likely to exit or downsize the farm in the next five years. In addition, the majority of respondents in all systems were not willing to motivate the next generation for taking dairying as a profession. The perceived reasons for withdrawal tendencies (exit intention and not willing to motivate next generation) were investigated and found that inadequate income from dairying, poor respect for farmers associated with dairying in the society, drudgery associated with dairy work, and employment opportunities in non-farm sector were reported as the major reasons (Table 3). Overwhelmingly, households in CLS I.० and CLS I5 perceived inadequate income from dairy as the basis for withdrawal from dairying. 


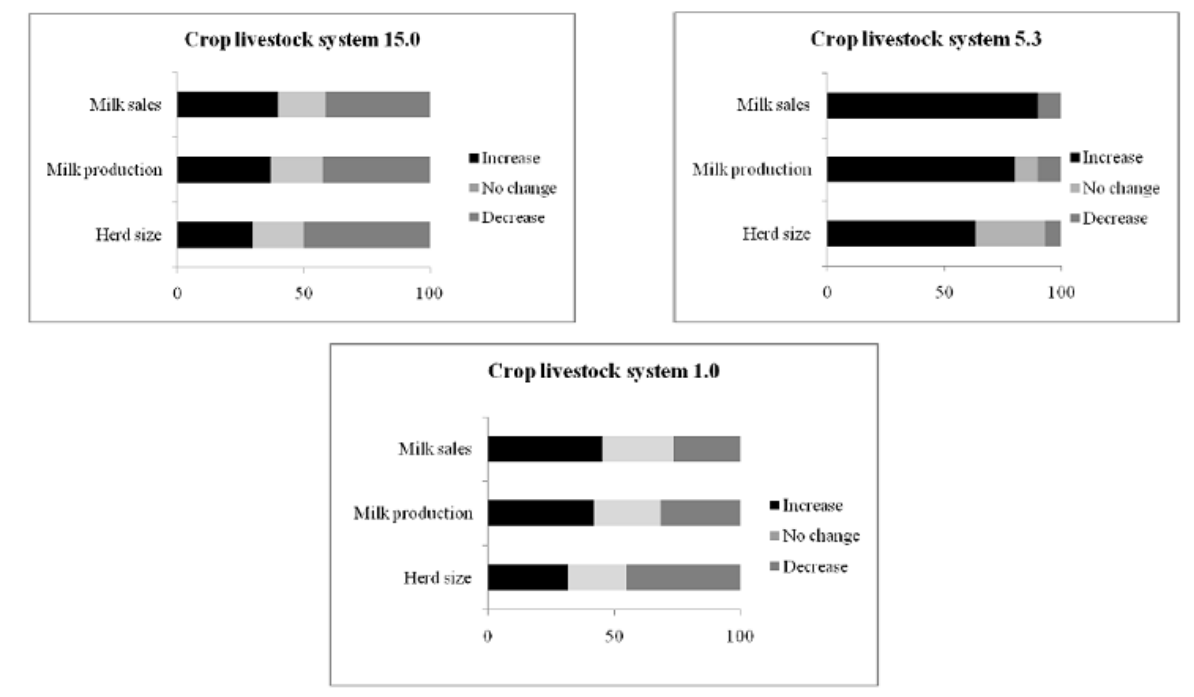

FIGURE 1

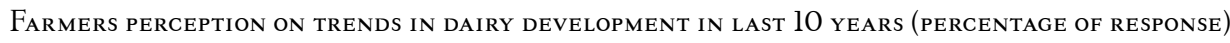

SOURCE: OWN ELABORATION
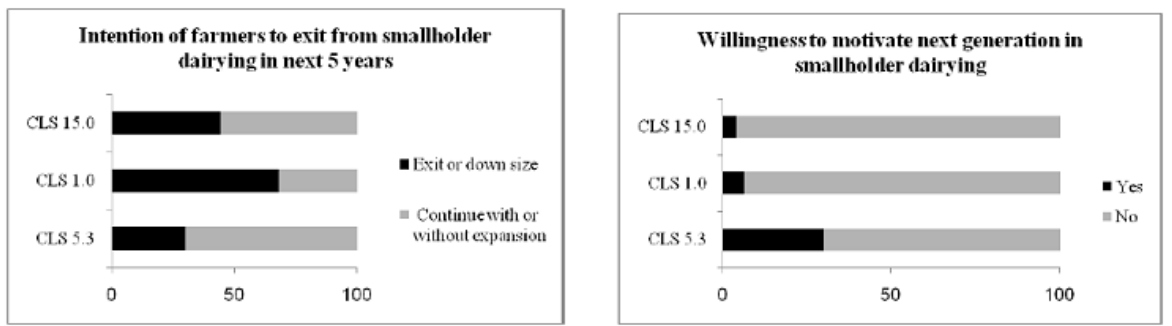

FIGURE 2

FARMER'S FUTURE PLANS ON SMALLHOLDER DAIRYING

SOURCE: OWN ELABORATION

\section{Discussion}

This study shows that smallholder dairying is a profession of landless, marginal and small landholding farmers, lower income groups and women. This is in concurrence with the past and recent findings in India (Rao \& Birthal, 2002; Khode, Sawarkar, Banthia, Nande \& Basunathe, 2009; Basu, 2009a, 2009b; Rathod, Sariput, Nikam \& Vajreshwari, 20II; National Dairy Development Board, 2013; Daftary, 2018) and other South Asian countries (Rao \& Birthal, 2008). Thus, from the past to present, dairying is predominantly associated with the lower strata / income groups of the rural society.

The findings of present study on diversification of sources of income are similar to the observation of Sujithkumar (2007) who reported an average of two sources of income per household. Further, majority of households in all farming systems had income contributions from non-farm sector. National Sample Survey Organisation (2014) reported $57 \%$ of income was from non-farm business and wages/salary in Tamil Nadu state. This may be attributed to the growth of employment opportunities in the rural non-farm sector from $18.6 \%$ to $32.1 \%$ over 1983 and 2009-I0 (Kumar, Kumar, Singh \& Shivjee, 20II). Major sources of non-farm income were through wage/salary employment or business in retailing, construction, transport, textile and communication (Binswanger- 
Mkhize, 2013). In CLS 5.3 greater level of non-farm sector contribution was noticed when compared with the two other two systems. This may be accounted to high urbanisation (IIO6 persons per sq $\mathrm{km}$ against the state average of 555 persons per sq $\mathrm{km}$ ) resulting in development of service sector within the locality, and high wages/salaries and opportunities in labour deficit adjoining state when compared to other two farming systems.

In general, the development of non-farm sector and distress in agriculture and allied sector has been promoting migration among the majority of the dairying households. Similar to the findings of present study, Deshingkar (20I0) and Sato (20II) found $52 \%$ and $42 \%$ of rural households respectively had out migration. At the same time, the contribution of dairying to household income accounted for around $25 \%$ of family income. In 2002-03 livestock sector contributed $4 \%$ to the household income and it rose to 13\% in 2012-13 (National Sample Survey Organisation, 20I4). Thus, the hike in the role of dairying is noticed. This may be attributed to increasing demand for milk and other livestock products due to urbanisation, population growth and changing consumption pattern (Delgado, Rosegrant, Steinfeld, Ehui \& Courbois, 1999). But among the farming systems, greater contribution of dairy to household income was noticed in CLS 5.3 and CLS 15.0 . This may be attributed to higher price fetched for milk in CLS 5.3 and presence of organised sector in CLS 15.0. Thus, higher price for milk in CLS 5.3 was encouraging the farmers to increase herd size, production and sales in last ten years. The higher share of dairying to family income in CLS 5.3 and CLS 15.0, better prices for milk in CLS 5.3 and the strong presence of organized sector in CLS I5.0 may be reasons for continuing dairying as a profession in the short term. In the case of CLS I.O, the absence of organized sector, relying more on informal marketing channel (vendors and consumers) which is predominant pattern in India (Singh \& Datta, 20I0; Bardhan, Sharma \& Saxena, 20I2), poor price, subsistence nature of dairying characterized by low yielding animals and low contribution of dairying to the family income may be driving the farmers to exit. Added to above, CLS I.o has more than two-fifth of the state's cattle population and the dominant reason for dairying here was to meet home needs against the prime trend of rearing dairy animals for additional income (Ramkumar, Rao \& Waldie, 2004; Geetha \& Lavanya, 2013). But invariably in all farming systems, the overwhelming majority are not willing to motivate the next generation to take up dairying. Thus, in general the dairy farming households have an exit tendency from dairying activities in the near future or the next generation as a result of inadequate income, poor respect for farmers associated with dairying and opportunities in non-farm sector.

Similar trend of withdrawal from dairying / agriculture were reported in other parts of India. In Pondicherry, an adjoining Union Territory to Tamil Nadu, 20\% quit dairying during the period 2005 and 2010 (Athilakshmy, Sunitha \& Rao, 20I3). Jodhka (20I4) found that the proportionate of households not owning cattle increased from Io to $42 \%$ between I988-89 to 2008-09. In South India, Ramkumar et al. (2004), Ravikumar, Reddy and Rao (2007) and Jothilakshmi, Thirunavukkarasu and Sudeepkumar (2014) observed that women and men engaged in smallholder livestock farming were middle to old aged and there was limited participation of youth. Further, among the reasons for exit intention / not motivating next generation, inadequate income was reported as the top most reason in all the farming systems in this study. Singh, Singh and Kingra (2009) observed similar reason and reported that because of low income, $64 \%$ of small peasantries moved out of smallholder agriculture. While Kala, Reddy and Srinath (2013) observed that inadequate income in rural was the reason for quitting the rural occupation. In other Asian countries too similar pattern were observed. In Bangladesh, Uddin, Brümmer and Peters (2013) observed that $31 \%$ of farmers are likely to exit from dairying in future and reported non-farm income as one of the factors that influence exit. In China the smaller dairy farms (I to 4 animals) have declined by $15 \%$ in the period 2008 to 201 due to uncertainty of market, migration, increase of opportunity costs and disease outbreaks (Lior, 20I4).

Thus role of smallholder dairying as livelihood option in India is in transition as similar to other Asian countries. Further, withdrawal tendencies from dairying in India are not an isolated event, but is part of a more widespread total withdrawal tendency from smallholder agriculture (Jodhka, 20I4). On the other side, the emerging vacuum in the production side through withdrawal of smallholders may be compensated through the on-going 
process of intensification within remaining smallholder dairy (Duncan et al., 2013) and / or specialized dairy farms with larger herd size (Shah \& Dave, 2010) which are noticed in the proximity of highly urbanised areas.

\section{Conclusion}

Smallholder dairying in India is a profession of marginalised sections of the rural society as similar to past but with middle to old aged persons. Productivity of dairy animals has increased and varying level of marketing opportunities exist. At the same time, contrary to past, increasing share of non-farm sector and dairying in household income is noticed. It can be inferred that, at least in short term, the share of non-farm source to family income and migration intensity may not be driving away the farmers from smallholder dairying. The marketing opportunities and price of milk were playing a crucial role in near future on the course of dairying in the croplivestock systems. Thus, the chances of farmers engaging in smallholder dairy in the next few years will be likely to be more in farming systems with better milk marketing opportunities. But in the long run, the scope of smallholder dairy as a profession becomes more doubtful across the farming systems on account of structural changes in the macro economy and newer rural aspirations.

\section{References}

Athilakshmy, S., Sunitha, P., \& Rao, S. V. N. (2013). Temporal changes in the dairy farming scenario in Puducherry. Indian Journal of Dairy Science, 66(6), 535-539.

Bardhan, D., Sharma, M. L., \& Saxena, R. (2012). Market participation behavior of smallholder dairy farmers in Uttarakhand: A disaggregated analysis. Agricultural Economics Research Review, 25(2), 243-254. Retrieved from https://ideas.repec.org/a/ags/aerrae/137367.html

Basu, P. (2009a). Success and failure of crossbred cows in India: A place-based approach to rural development. Annals of the Association of American Geographers, 99(4), 746-766. https://doi.org/10.1080/000456009031 02808

Basu, P. (2009b). Villages, women, and the success of dairy co-operatives in India. Cambria Press.

Binswanger-Mkhize, H. P. (2013). The stunted structural transformation of the Indian economy. Economic \& Political Weekly, 48(26-27). Retrieved from https://www.epw.in/journal/2013/26-27/review-rural-affairs-rev iew-issues/stunted-structural-transformation-indian

Chandramouli, P. (20II). "Rural urban distribution of population”. Census of India. Retrieved from http://censu sindia.gov.in/20II-prov-results/paper2/data_files/india/Rural_Urban_20Iı.pdf

Daftary, D. (2018). Cattle, milk and women's labour: The politics of contemporary dairying in Gujarat. Economic \& Political Weekly, 53(22), 43-50. Retrieved from https://www.epw.in/journal/2018/22/special-articles/catt le-milk-and-womens-labour.html

Delgado, C., Rosegrant, M., Steinfeld, H., Ehui, S., \& Courbois, C. (1999). Livestock to 2020: The next food revolution. International Food Policy Research Institute. Discussion paper 28. Retrieved from http://www. fao.org/ag/againfo/resources/documents/lvst2020/20201.pdf

Deshingkar, P. (2010). Migration, remote rural areas and chronic poverty in India. Overseas Development Institute. ODI working paper 323 and CPRC working paper 163. Retrieved from https://www.odi.org/publications/4 53I-migration-remote-rural-areas-and-chronic-poverty-india 
Duncan, A. J., Teufel, N., Mekonnen, K., Singh, V. K., Bitew, A., \& Gberemedhin, B. (2013). Dairy intensification in developing countries: Effects of market quality on farm-level feeding and breeding practices. Animal, 7(I2), 2054-2062. https://doi.org/10.1017/S1751731113001602

Geetha, K. T., \& Lavanya, V. L. (2013). Economic analysis of dairy farming in Vellalore village in Coimbatore district. Journal of Economic and Social Development, 9(I), 25-37.

Government of India. (2015). 19th Livestock Census. New Delhi: Department of Animal Husbandry and Dairying, Ministry of Agriculture. Retrieved from http://dahd.nic.in/sites/default/filess/Livestock\%20\%205_o.pdf

Government of India. (2017). India emerging as a leader among milk producing nations. Press Information Bureau, Government of India, Ministry of Agriculture \& Farmers Welfare. Retrieved from http://pib.nic.in/news ite/PrintRelease.aspx?relid=172017

Jodhka, S. S. (20I4). Emergent ruralities: Revisiting village life and agrarian changes in Haryana. Economic \& Political Weekly, 49(26-27). Retrieved from https://www.epw.in/journal/20I4/26-27/review-rural-affairs-rev iew-issues/emergent-ruralities.html

Jothilakshmi, M., Thirunavukkarasu, D., \& Sudeepkumar, N. K. (20I4). Exit of youths and feminization of smallholder livestock production: A field study in India. Renewable Agriculture and Food Systems, 29(2), I46-150. https://doi.org/10.1017/S17421705130000IX

Kala, K. S., Reddy, A. V., \& Srinath, P. (2013). Is it push or pull? Recent evidence from migration in India. Journal of International Migration and Integration, I4(2), 287-306. Retrieved from https://link.springer.com/articl e/I0.1007/SI2134-0I2-024I-9

Khode, N. V., Sawarkar, S. W., Banthia, V. V., Nande, M. P., \& Basunathe, V. K. (2009). Adoption of improved dairy cattle management practices under Vidarbha development programme package. Indian Research Journal of Extension Education, 9(2), 80-84. Retrieved from https://www.researchgate.net/publication/266174902_Adoption_of_Improved_Dairy_Cattle_Manage ment_Practices_under_Vidarbha_Development_Programme_Package

Kumar, A., Kumar, S., Singh, D. K., \& Shivjee. (20II). Rural employment diversification in India: Trends, determinants and implications on poverty. Agriculture Economics Research Review, 24(2), 361-372. Retrieved from https://cgspace.cgiar.org/handle/10568/12418

Lior, Y. (20I4). Milk quality in China. Milkproduction.com. Retrieved from http://www.milkproduction.com/L ibrary/Editorial-articles/Milk-quality-in-China-/

Mehrotra, S., Parida, J., Sinha, S., \& Gandhi, A. (20I4). Explaining employment trends in the Indian economy: 1993-94 to 20II-I2. Economic \& Political Weekly, 59, 49-57. Retrieved from https://www.researchgate.net/pu blication/286723590_Explaining_employment_trends_in_the_indian_economy_1993-94_to_20II-I2

National Dairy Development Board. (2013). External monitoring and evaluation of national dairy plan phase I. Karnal: author.

National Sample Survey Organisation. (2014). Key indicators of situation of agricultural households in India. New Delhi: author.

Ramkumar, S., Rao, S. V. N., \& Waldie, K. (2004). Dairy cattle rearing by landless rural women in Pondicherry: A path to empowerment. Indian Journal of Gender Studies, II(2), 205-222. https://doi.org/10.1177/09715215 0401100204

Rao, P., \& Birthal, P. S. (2002). Crop-livestock systems in India: Research and policy issues. Icrisat. Retrieved from http://www.icrisat.org/PDF/Pbi.pdf 
Rao, P., \& Birthal, P. S. (2008). Typology of mixed crop-livestock systems in India. In P. Rao and P. S. Birthal, Livestock in mixed farming systems in South Asia (pp. 39-78). New Delhi: National Centre for Agricultural Economics and Policy Research; International Crops Research Institute for the Semi-Arid Tropics. Retrieved from https://core.ac.uk/download/pdf/I2104500.pdf

Rathod, P. K., Sariput, L., Nikam, T. P., \& Vajreshwari, S. (20II). Socio-personal profile and constraints of dairy farmers. Karnataka Journal of Agricultural Sciences, 24(4), 619-62I.

Ravikumar, S., Reddy, K. V. R., \& Rao, B. S. (2007). Farmers' choice for cost recovery of veterinary services in different livestock holding systems: A case study of India. Livestock Research for Rural Development, 19(5). Retrieved from http://www.lrrd.org/lrrdı9/5/kumai9066.htm

Sato, K. (20II). Employment structure and rural-urban migration in a Tamil Nadu village: Focusing on differences by economic class. Southeast Asian Studies, 49(I), 22-5I. Retrieved from https://kyoto-seas.org/wp-content /uploads/20II/II/490I0I.pdf

Shah, J., \& Dave, D. (2010). A shift from traditional dairying to market oriented organized dairy farming-plausible factors responsible for structural transformation in Indian dairy sector. Indian Journal of Agricultural Economics, 65(2), 298-307. Retrieved from https://ideas.repec.org/a/ags/inijae/204683.html

Singh, K., Singh, S., \& Kingra, H. S. (2009). Agrarian crisis and depeasantisation in Punjab: Status of small/ marginal farmers who left agriculture. Indian Journal of Agricultural Economics, 64(4), 585-603. Retrieved from https://ageconsearch.umn.edu/record/204658/files/05-Karam\%20Singh.pdf

Singh, S. R., \& Datta, K. K. (2010). Understanding value addition in Indian dairy sector: Some perspectives. Agricultural Economics Research Review, 23, 487-493. Retrieved from https://ideas.repec.org/a/ags/aerrae /96924.html

Sujithkumar, P. S. (2007). Livelihood diversification: A case study in rural Tamil Nadu. The Indian Journal of Labour Economics, 50(4), 715-722. Retrieved from http://www.isleijle.org/ijle/issuepdf/eabod2II-c6d5-4910 -8420-6228e85b6973.pdf

Uddin, M. M., Brümmer, B., \& Peters, K.-J. (2013). Modelling factors affecting the decision to exit dairy farming in Bangladesh: A two-stage regression analysis. In E. Tielkes (ed.), Proceedings of conference on agricultural development within the rural-urban continuum. Stuttgart and Hohenheim: International Institute of Tropical Agriculture. Retrieved from http://www.tropentag.de/2013/abstracts/links/Uddin_Y TTPSBLT.pdf

Udo, H. M. J., Aklilu, H. A., Phong, L. T., Bosma, R. H., Budisatria, I. G. S., Patil, B. R., ... Bebe, B. O. (2oıI). Impact of intensification of different types of livestock production in smallholder crop-livestock systems. Livestock Science, 139(I-2), 22-29. https://doi.org/10.10I6/j.livsci.20II.03.020

World Bank. (2008). World Development Report 2008: Agriculture for development. Washington: World Bank.

\title{
Notes
}

* Research article

\author{
Licencia CC BY-4.0
}

